\title{
“PRE-FACTOR" IN THE TAX ON GOODS AND SERVICES
}

\author{
KATARZYNA KOPYŚCIAŃSKA ${ }^{l}$
}

\begin{abstract}
Since 1 January 2016, there have been new provisions in force of the Act on Tax on Goods and Services, introducing the requirement to use the so-called "prefactor" of the input tax deduction by taxpayers. Already before the amendments, the VAT Act contained provisions on proportional deduction (Art. 90). However, the pre-factor was then applied at a different level. In this paper the essential issue is to establish the right of taxable persons (in particular a self-government unit) to a partial deduction of input tax with respect to mixed costs on the basis of the proportion of sales, referred to in Art 90/3 of the Act on Tax on Goods and Services, as well as to examine the merits of such solutions and to draw attention to possible elements of non-compliance with the rules of the tax while accounting for the CJEU case-law.
\end{abstract}

\section{Keywords}

Value added tax; due tax; deduction; "pre-factor"; active taxpayer

\section{JEL Classification: H23, H25, K34}

\section{Introduction}

Art. 90 of the VAT Act (Act of 11 March 2004 on the Tax on Goods and Services) obligates taxpayers to attribute input tax to a sale which confers the right of deduction and which does not confer this right. When the input tax cannot be unambiguously attributed to one of the above sales categories, the deduction factor is applied. To put it simply, one might say that Art. 90 is predominantly applied when taxpayers,

Associate Professor at the Department of Finance Law, Faculty of Law, Administration, and Economics, University of Wrocław. She is a member of Information and Organization Center for the Research on the Public Finances and Tax Law in the Countries of Centre of Eastern Europe. Contact mail: katarzyna. kopyscianska@uwr.edu.pl. 
within their economic activity, are involved in a sale that is mixed in nature - and that is both subject to VAT and exempt from it. In each case, however, it is still an economic activity that is subject to VAT (Bełdyga, 2014).

\section{Legal Basis for Pre-Factor Regulation}

The provisions cited above of Art. 90/1-3 of the VAT Act constitute the implementation of Art. 17/5 and Art. 19 of the Sixth Council Directive (77/388/EEC - Common system of value added tax) which today correspond to Arts. 173 and 174 of Directive 112 (Council Directive 2006/112/EC on the common system of value added tax). Pursuant to Art. 173/1 of this Directive in the case of goods and services used by a taxable person both for transactions in respect of which VAT is not deductible, only such proportion of VAT as is attributable to the former transactions shall be deductible. The deductible proportion is determined, in accordance with Arts. 174 and 175 for all transactions carried out by the taxable person. However, according to Art. 173/2 the Member States may take the following measures:

a) Authorize the taxable person to determine a proportion for each sector of his business, provided that separate accounts are kept for each sector,

b) require the taxable person to determine a deductible proportion for each sector of his business and keep separate accounts for each sector,

c) Authorize or require the taxable person to make the deduction on the basis of the use made of all or part of the goods and services

In accordance with Art. 174/1, the deductible proportion is made up of a fraction comprising the following amounts:

a) as numerator, the total amount, exclusive of VAT, of turnover per year attributable to transactions in respect of which VAT is deductible pursuant to Arts. 168 and 169;) as denominator, the total amount, exclusive of VAT, of turnover per year attributable to transactions included in the numerator and to transactions in respect of which VAT is not deductible.

Focusing on domestic regulatory enactments, it should be indicated that the provisions of Art. 86/1 and Art. 90 of the VAT Act do not define the meaning of repayment, as contained in Art. 90/1 of the VAT Act - an action in respect to which the taxpayer is not Authorized to lower the tax due, and therefore they do not provide a straight answer as to - how the taxpayer should act in the case when the purchases made involve transactions that are taxed (exempt from tax), as well as transactions that are not subject to the provisions of the VAT Act, while there exists no possibility to attribute the purchases to only one of the categories. As the applicant rightly points out, the repayment was the subject of analysis of the 
domestic courts which recognized that the scope of this repayment did not cover transactions outside the VAT system (not referring to the taxpayer's non-economic activity) which may not exert an influence on the decision on the right of deduction. Thus, in the denominator of the proportion factor of the input tax payment, referred to in Art. 90/3 of the VAT Act, there should be no expenditures on goods and services which are intended for the taxpayer's non-economic activities (Zubrzycki, 2017).

Meanwhile, the new regulatory enactments are applicable when the taxpayer conducts an economic activity as well as other kinds of activities, incurring costs relating to purchasing goods and services used for all of his activities.

According to Art. 86/2a of the VAT Act, the new provisions refer to taxpayers who use goods and services acquired for both economic and non-economic activities. If the taxpayer conducts simultaneously an activity that is subject to VAT (i.e. taxable or exempted from tax) and not subject to VAT (do not fall within the scope of the VAT Act), the input VAT deduction is allowed only to the extent to which the expenditures can be attributed to the activity subject to VAT. The new provisions are supposed to make the implementation of this rule possible.

With respect to the relationship between the new pre-factor of deduction determined on the basis of Art. 86/2a-2h of the VAT Act and the proportional deduction based on Art. 90 of the same act, it is multi-leveled in nature, which means that the taxpayer should first determine the amount of input VAT while accounting for the pre-factor and only then apply the deduction proportion, referred to in Art. 90 of the VAT Act, to the amount, thus determined.

In accordance with the position taken by CJEU in its judgment C- 437/06 in the case when the taxpayer engages in an economic activity, taxable and exempted from tax, and in an activity of non-economic character, which do not fall within the the scope of the Sixth Council Directive 77/388/EEC: a uniform basis of assessment, deduction of the VAT relating to expenditure connected with the issue of shares and atypical silent partnerships is allowed only to the extent that that expenditure is attributable to the taxpayer's economic activity within the meaning of Art. 2/1 of that Directive. In the view of CJEU, "in line with the principle of neutrality, only tax paid on a deductible economic activity should be subject to deduction. There should be no right of deduction for transactions which are not linked to the economic activity. The Member States should implement such provisions which would ensure this objective.

The new paragraph 2a added to Art. 86 of the VAT Act imposes a new obligation on the taxpayer which is relating to the input tax apportionment. In light of this provision: in the case of acquisition of goods and services used for the taxpayer's 
economic activity and for non-economic purposes, with the exception of personal purposes, to which Arts. 7/2 and 8/2 apply, and for purposes referred to in Art. 8/5 in the case, which is referred to in this provision, when it is not possible to attribute these goods and services entirely to the taxpayer's economic activity, the amount of input tax, referred to in Paragraph 2, is calculated in accordance with the method to determine the scope of use of goods and services acquired for business purposes, hereinafter referred to as "the proportion determination method". The method used to determine the proportion should be tailored to the specificity of the taxpayer's activity and acquisitions he makes.

However, attention should be drawn to the content of Art. 86/22 of the VAT Act, in which we read, "Minister competent to public financial matters may establish by Regulation the method of proportion determination considered to be the most suitable for some taxpayers in terms of the characteristics of their activities and acquisitions, and indicate data on the basis of which the input tax amount can be calculated using this method of proportion determination, while taking into account the specificity of some taxpayers' economic activity and economic determinants. The Ministry of Finances applied the legislation contained in the cited Art. and issued on its basis the Regulation of 17 December 2015 addressed to local selfgovernment units which in their calculation of the pre-factor should in the first place learn about the provisions pertaining to the solutions addressed especially to them and try to calculate the pre-factor in accordance with the norms contained therein.

On the basis of the pre-factor regulation cited above, within the local selfgovernment units, the pre-factor is calculated separately for:

- every budgetary unit;

- every budgetary establishment;

- the office providing services to LSGU (city council office, Gmina's office, Marshal's Office, District Governor's Office).

Although those units as a whole form one VAT payer, a local self-government unit is not Authorized to determine one total proportion but it is required to determine a proportion separately for every individual organizational unit. Thus, depending on whether the LSGU carried out the centralization before 1 October 2016 or before 1 January 2017, or possibly before 1 January 2016, unambiguous rules were issued establishing when to deduct the tax charged using the pre-factor and how it should be calculated. The above considerations were confirmed by the individual interpretation (Head of the Tax Chamber of Łódź: no. 1061-IPTPP3.4512.371.2016.3MWj) "Pursuant to Art. 86/2b of the Act, the method determining the proportion corresponds most effectively to the specificity of the activity performed by the taxpayer and his acquisitions if: the method ensures that the tax due is reduced 
by the amount of the tax charged exclusively with respect to the input tax amount, proportionally attributable to a taxable transaction carried out within the taxpayer's economic activity and reflects objectively the portion of expenditures attributable to the economic activity and to other than economic purposes, with the exception of personal purposes, to which Arts. 7/2 and 8/2 apply, and to purposes referred to in Art. $8 / 5$ - in the case, referred to under this provision when it is not possible to attribute all of those expenditures to the economic activity" (Head of the Tax Chamber of Łódź: no. 1061-IPTPP3.4512.371.2016.3MWj). It should be noted that similar to the application of the "classical" proportion arising from the Art. 90 of the VAT Act, the new Art. 86/2a of the Act requires the apportioning of the amounts of the input tax between the economic activity and non-economic activity (...) when attributing those goods and services as a whole to the taxpayer's economic activity is not possible. Thus primacy would be accorded to a direct allocation of the input tax amounts (also for the amounts of input tax which was separated under one invoice, and only if it proved to be impossible (in particular for the so-called general costs), the taxpayer would be required to apply the "pre-factor".

Moreover, in accordance with paragraph 2a added to Art. 86 of the VAT Act, the apportioning of the tax charged within the "pre-factor" is carried out in the case of acquiring services used for purposes of the taxpayer's economic activity (subject to VAT: taxable or exempted) and for other purposes than those relating to his economic activity. The obligation to carry out the above-cited apportioning would thus be referring to VAT payers receiving benefits from an economic activity within the meaning of Art. 15 paragraphs 2 and 3 of the VAT Act and from a noneconomic activity (Namysłowski, Borowski, Sajnaj, 2016: 119).

\section{Apportionment Methods of Tax Charged Using "Pre-factor"}

In light of Art. 86/2c of the VAT Act, while choosing the method to determine proportions the following data may be used in particular:

- The annual average number of persons performing only tasks relating to the economic activity within the annual average number of persons performing tasks within the economic activity and outside it. This method, which is based on the criteria relating to the allocation of persons to perform specific tasks will be of little use in practical terms. In general, a public sector does not divide tasks so strictly (after all, that would have to arise from employment contract/rules, etc.) Persons employed by this type of taxpayers perform a variety of work, and such a strict division of tasks among employees is rarely affected. 
- The annual average number of working hours devoted to tasks relating to the economic activity within the overall annual average number of working hours devoted to tasks relating to the economic activity and outside it. Similar remarks can be cited with respect to this method. A division by working hours is not used by taxpayers, and on top of that, it is difficult to determine and to estimate. Such a key to apportioning would have to draw on corresponding documents/records.

- The annual turnover of the economic activity within the taxpayer's annual turnover from the economic activity increased by the income received from a different activity, including grants, subsidies and other extra donations similar in nature, obtained for the purpose of financing the taxpayer's noneconomic activity. The term "turnover" used in Art. 86/2c/3 of the VAT Act will be interpreted the same as in Art. 90 thereof. Turnover should be understood as the amount due to less VAT. As indicated in the explanatory note on the draft Act: the category "revenue/income" shall also encompass grants, subsidies and other extra subsidies similar in nature which the entity receives to finance his non-economic activity. This category will thus not include grants used for the economic activity (e.g. restricted grant or the socalled cost subsidy, e.g. purchasing a machine to manufacture goods sold by the taxpayer) or grants intended for another entity to perform activity which does not fall within the VAT scope (Namysłowski, Borowski, Sajnaj, 2016: 119). The legislator, however, failed to show how to treat a grant received for "mixed" purposes (e.g. grant received for wages of the staff performing tasks within the economic and non-economic activity). Taxpayers should not treat this kind of grant in its entirety as a grant intended for the activity that does not fall within the VAT scope, for then, in increasing denominator they reduce the scope of the input tax deduction. This kind of grant should be apportioned by taxpayers according to the most adequate, from the point of view of the taxpayer and his activity, apportioning key.

- The annual average surface area used for the economic activity within the overall annual average surface area used for the economic and non-economic activity. Surface area allocation appears to be a method of little use, for not many taxpayers carry out a strict division of surface area (rooms) where they generate income from the economic and non-economic activity. While applying this method, there is also another problem of how to determine and divide the area. What seems the most appropriate in this case is to follow the rules specified under property tax (Selera, 2015).

Based on Art. 86/2d of the VAT Act, in order to calculate the amount of input tax for the purpose of applying the "pre-factor", the data from the last year is used. The taxpayer starting to pursue his economic and non-economic activity in the tax year 
concerned, with a view to calculate the input tax amount so as to apply the "prefactor'adopts data calculated as estimates according to the forecast which has been agreed with the head of a tax office in the form of a report (Art. 86/2e of the VAT Act). Pursuant to Art. 86/2g of the VAT Act, the proportion effective as of 1 January 2016 is determined percentages on an annual basis. This proportion is rounded up to the next whole number. The provisions of Art. 90 paragraphs $5^{2}, 6^{3}, 9 \mathrm{a}^{4}$ and $10^{5}$ of the VAT Act apply respectively.

Moreover, the requirement to correct the pre-factor calculated based on Art. 86/2a of the act is indicated in Art. 90c of the same act (including data for the completed tax year). Particularly complicated will be the method to calculate the deduction scope of the input tax for a property, as here we might have to calculate as many as 3 factors: (a) surface area key based on Art. 86/7b of the VAT Act, (b) pre-factor, (c) factor).

\section{Essential Characteristics of Gmina's Functioning}

Pursuant to Art. 15/2 of the VAT Act an economic activity encompasses any activity of producers, traders or persons supplying services, including entities exploiting natural resources and farmers, as well as the activity of persons engaged in a liberal profession. The economic activity covers in particular activities involving the use of goods or intangible and legal values in a continuous manner for lucrative purposes.

The economic activity is not dependent on a result, and therefore it does not need to bring any noticeable effects, in the first place including the financial ones. The economic activity does not cover an activity in which no economic risk on the part of the seller or service supplier materializes and, thus, there is no liability for damages caused as the result of carrying out this activity. An important aspect is that every task performed within the economic activity has to be verified separately. The economic activity which in the case of LSGU is not of an economic nature is the one linked to the statutory activity. LSGUs are entities which largely carry

2 The turnover, referred to in paragraph 3, does not include the turnover attributable to supplying goods and services, which, based on the provision on the income tax, are classified by the taxpayer as property, as non-current and intangible assets subject to depreciation, and land and the right to perpetual usufruct of land, if they are classified as the taxpayer's non-current assets - used by the taxpayer for the purpose of his business.

3 The turnover referred to in paragraph 3 does not include the turnover attributable to transactions referring to 1) incidental transactions pertaining to property and incidental financial transactions; 2) services listed in Art. $43 / 1$ points 7,12 and $38-41$, to the extent these transactions are incidental in nature.

$4 \quad$ Hile determining the proportion, pursuant to paragraphs 2-6, the tax amount is not included in the turnover.

5 In the case the proportion determined pursuant to paragraphs 2-8: 1) Exceeded $98 \%$ and the amount of the input tax that is not deductible, arising from the application of this proportion, was less than 500 PLN on an annual basis - the taxpayer is authorized to assume that this proportion equals $100 \%$; 2 ) It does not exceed $2 \%$ - the taxpayer is authorized to assume that this proportion is equal to $0 \%$. 
out duties conferred on them. This is to satisfy the collective needs of a local community relating to its daily functioning. It is, therefore, crucial to note that LSGUs have not been established to operate like a classical entrepreneur. The units perform tasks for payment or free of charge to which they have been appointed under the law. The amounts paid by persons using the above-mentioned services are classified as administrative fees, with the provision of those services being considered to be public services. The activity of entities governed by public law is inherently non-commercial in nature. In its principle, their objective is not to sell goods for payment or provide services like it is done within a free market, for their activities are linked to the public law sphere. Therefore, the legislator introduced separate rules for entities from this sector (Sokołowska-Strug 2016: 104).

Pursuant to Art. 15/6 of the VAT Act "public authorities and offices servicing those authorities are not considered to be taxpayers within the scope of tasks conferred by separate provisions of law for the purpose of implementing tasks they have been appointed for, excluding work performed under civil-law contracts".

A local self-government unit providing services by virtue of administrative provisions, and considering the fact that it charges fees in spite of this, after all, it cannot be considered to be a VAT payer in this context. The services the local self-government unit supplies are provided for in law, constituting an activity that is not economic in nature. It should, therefore, be noticed that when the taxpayer, and in this case, it is the LSGU, purchases goods or services, and as the result, it can attribute this purchase to the relevant activity, then if this activity is an activity which:

- is not of economic nature - then the unit does not have the right of the input tax deduction;

- is economic, exempted from VAT - then the unit does not have the right of the input tax deduction;

- is economic that is taxed by VAT - then the unit has the right to the input tax deduction (Sokołowska-Strug, 2016: 104).

\section{Application of Provisions in Practice}

The classification of the costs incurred within the individual types of activities VAT taxable, taxable and VAT exempted and an activity that is outside the VAT scope is what causes the greatest number of problems to LSGUs. An exception to this is when LSGUs have the possibility of attributing expenditures directly - e.g. exclusively to an activity that is taxed by VAT (expenditures incurred in relation to the renovations of rooms which are all rented). However, a given expenditure 
is very likely to be used for the two types of activity carried out by the LSGU (those subject and not subject to VAT). The Head of the Tax Chamber of Bydgoszcz issuing the individual interpretation (no. ITPP2/443-868/13/17-S/RS) contended that "it is possible to apply any kind of apportioning with respect to purchases of goods and services provided that it guarantees the most accurate determination of the amount of input tax to be deducted".

It should be remembered that LSGU's activity is very specific - they implement tasks conferred on them through a number of entities being responsible for separate tasks - they carry out a "fragment" of the LSU's activity that was transferred to them (within this economic activity). The introduction of just one method of calculating the pre-factor applied centrally at the level of the entire LSGU would not account for the specificity of the multi-strand activity of the local self-government as a VAT payer nor for acquisitions made by individual organizational units. To give an example, the scope of the economic activity of LSGU is narrow in educational units, while considerably larger in budgetary establishments involved in water supply infrastructure or utilities.

Attributing the goods and services purchased to the LSU's particular activity and determining the method of the pre-factor calculation should, therefore, be carried out for every organizational unit separately. Adopting this solution is further confirmed by the regulation of the Minister of Finances issued on the basis of Art. 86/22 of the VAT Act (see the legal basis), where the recommended method with respect to the pre-factor calculation has been determined, which should be used by every organizational unit separately.

Moreover, the provisions of the VAT Act provide for the possibility to apply a different method of the pre-factor calculation in the case when the method recommended will not, in the taxpayer's opinion, correspond most accurately to the particularities involved in the taxpayer's activity and acquisitions made.

In the practice of LSGUs, it is extremely difficult to affirm, within the framework of individual tax interpretations, that it is possible to use other methods with respect to pre-factor calculation than the one already recommended (although in the taxpayer's opinion the other method is more suitable to the specific characteristics of the activity). This effectively means that LSGUs cannot use a different method merely because the recommended method is what has been intended for them. The local self-government units may try to defend their different position in this respect before administrative courts, yet many of them simply give up their VAT deductions, for they would rather avoid being involved in a long-lasting dispute.

This negative attitude of the tax authorities with respect to the issue discussed is reflected in the individual interpretation of the Head of the Tax Chamber of Łódź 
(no. 1061-IPTPP1.4512.699.2016.2.AK) in which it is argued that "The method proposed by Gmina with respect to determining the proportion (...) calculated as an annual proportion of the water supplied as represented in the total amount of water supplied to external customers and the proportion of sewage discharged as represented in the total volume of sewage from external consumers is not a method that could be recognized as most accurately corresponding to the specificity of the Gmina's activity and acquisitions made."

Finally, the tax authority contends that "for the local self-government unit, the legislator provided for one method to determine the scope of use in terms of goods and services acquired for the purpose of the economic activity, having recognized it as being suitable to the specificity of those taxpayers' activity and acquisitions made."

One thing is to be concluded from the above: LSGUs theoretically, pursuant to the provisions of the VAT Act, are authorized to apply different methods with respect to the pre-factor calculations, but in practice, it is the recommended method that the tax authorities consider being the most appropriate.

As the result, LSGUs either do not deduct VAT from their expenditures, with respect to which they are required to apply the pre-factor, or they use the method pursued by the legislator which is unfavorable in terms of the amount of VAT deductions, so as not to risk getting involved in a dispute (Zajączkowski, 2016: 26).

\section{Conclusions}

Every organizational unit that is subordinate to a local self-government unit is required to determine by itself the level of the pre-factor and the deduction proportion, and thus every year it is also required to sum up again and to verify data. This is not a small feat for the accounting and record-keeping systems of local self-government units in the context of the changes implemented, and at the same time it brings about a considerable responsibility on the part of an official who carries out those calculations.

The tax and legal effects, although they were forecast considerably earlier by the doctrine, will only be verifiable in a couple of years. At the moment in the context of the changes implemented local self-government units need to establish themselves in the new reality. The new issue which is the application of the pre-factor in the tax on goods and services for the purpose of calculating the input tax amount in relation to the activity carried out by the taxpayers will certainly give rise to doubts 
concerning the interpretation and whose solution will only come with the judicial decisions made by administrative courts.

\section{References}

Bełdyga, T.: VAT w gminach (VAT in municipalities), Warszawa: Wolters Kluwer, 2014.

Namysłowski, R.: Borowski M., Sajnaj B., Centralizacja VAT w jednostkach sektora finansów publicznych (VAT centralization in the public financial units), Warszawa: C.H. Beck, 2016.

Selera, P.: "Prewspółczynnik" w podatku od towarów i usług od 2016 ("Pre-factor" in the Tax on Goods and Services since 2016), Podatki i Rachunkowość (Taxes and Accounting) no. 9 (2015).

Sokołowska-Strug, E.: VAT w jednostkach samorządu terytorialnego (VAT in local government units), Warszawa: C.H. Beck 2016.

Zajączkowski, W.: "Pre-wskaźnik" - podstawowe problemy interpretacyjne ("Pre-factor" basic interpretation problems), Monitor Podatkowy (Fiscal Jounral) no. 5 (2016).

Zubrzycki, J.: Leksykon VAT 2017 (Lexicon VAT 2017), Wrocław: Unimex - Oficyna Wydawnictwo, 2017.

EU: Sixth Council Directive 77/388/EEC - Common system of value added tax.

EU: Council Directive 2006/112/EC on the common system of value added tax.

EU: Court of Justice of the European Union: no. 93968.

PL: Act of 11 March 2004 on the Tax on Goods and Services, as amended.

PL: Regulation of the Minister of Finance of 17 December 2015 on the method of establishing the scope of use for goods and services acquired for business purposes for some taxpayers.

PL: Supreme Administrative Court: I FSK 491/16.

PL: Head of the Tax Chamber of Bydgoszcz: no. ITPP2/443-868/13/17-S/RS.

PL: Head of the Tax Chamber of Łódź: no. 1061-IPTPP1.4512.699.2016.2.AK.

PL: Head of the Tax Chamber of Łódź: no. 1061-IPTPP3.4512.371.2016.3MWj. 